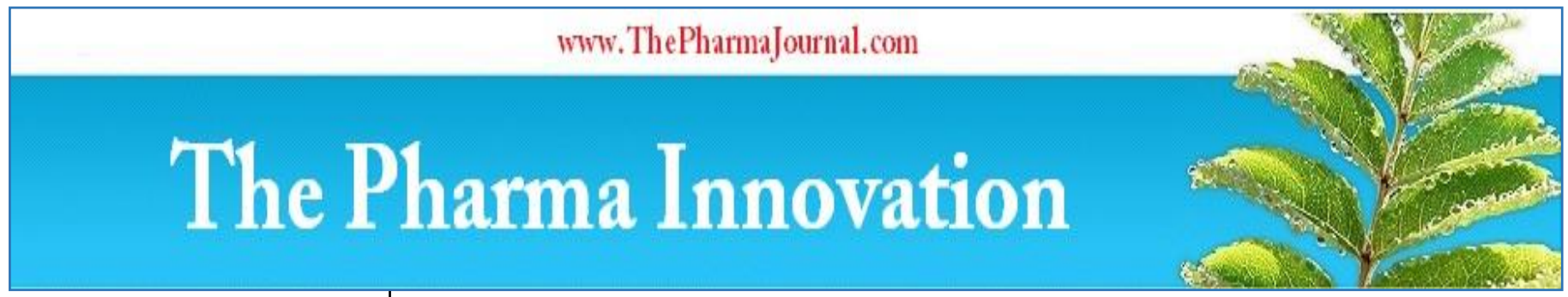

ISSN (E): 2277 - 7695

ISSN (P): 2349-8242

NAAS Rating: 5.03

TPI 2020; 9(3): 665-667

(C) 2020 TPI

www.thepharmajournal.com

Received: 08-01-2020

Accepted: 10-02-2020

\section{Deshmukh Bhakti A}

Department of Food processing technology, College of Food

Technology, VNMKV, Parbhani, Maharashtra, India

Pawar Vijaya S

Department of Food processing technology, College of Food Technology, VNMKV, Parbhani, Maharashtra, India
Corresponding Author: Deshmukh Bhakti A

Department of Food processing technology, College of Food Technology, VNMKV, Parbhani, Maharashtra, India

\section{Development of processing technology for formulation of chocolate coated legume bar and its sensory evaluation}

\author{
Deshmukh Bhakti A and Pawar Vijaya S
}

DOI: https://doi.org/10.22271/tpi.2020.v9.i31.4658

\section{Abstract}

The present investigation was aimed to development of chocolate coated legume bar with incorporation of different proportions of mothbean flour to date paste. To standardize the processing technology and analyze the characteristics of legume bar viz., sensory characteristics of legume bar. The formulation was carried out using germinated mothbean flour, date paste, chocolate in Preparation of legume bar. Different formulation were made with variation in germinated mothbean flour level from 0 to $30 \%$ for $\mathrm{T}_{0}, \mathrm{~T}_{1}, \mathrm{~T}_{2}$, and $\mathrm{T}_{3}$ respectively. Prepared legume bar then evaluated for organoleptic properties with respects to colour and appearance, flavour, texture, taste and overall acceptability using 9 point hedonic scale. The results revealed that legume bar prepared with supplementation of $20 \%$ germinated mothbean flour with $80 \%$ date paste $\left(\mathrm{T}_{2}\right)$ secured highest score (i.e. 8.25) was superior as compared to rest of samples. It was seen that chocolate coating attracted all aged consumers. And was found that Legume bar prepared with mothbean and date paste was rich source of nutrients. Thus, mothbean can be well utilized as a functional ingredient for preparation of legume bar with good nutritional and date with medicinal value.

Keywords: Germinated mothbean flour, germination, dates, legume bar, energy bar chocolate coating, functional food, sensory evaluation

\section{Introduction}

Legumes are important nutritional source in developing countries. Chickpea, pigeon pea, lentil, urad bean, mung bean, lablab bean, moth bean, horse gram, pea grass pea, cowpea and faba bean are the major pulse crops grown in India. Legumes however, are said to have low protein and starch digestibility (Ghavidel and Prakash, 2007) ${ }^{[1]}$. Legumes are generally good sources of proteins and contain on an average from 18 to 25 percent. Among such legumes is mothbean. Its seeds contain $24.1 \%$ protein, $0.8 \%$ crude fibers, $1.3 \%$ fat, $3 \%$ ash, $9.6 \mathrm{mg}$ iron/100gm. (Fatema et al., 2011) ${ }^{[2]}$.

Phytochemicals are the bioactive compounds that occur naturally in plants. Leguminous seeds are important source of proteins and source of natural antioxidants. Legumes contain a number of phenolic compounds such as flavonoids, phenolic acids, and tannins. There is a considerable interesting finding natural phytochemicals and antioxidants from plants due to their role in the treatment and/or prevention of various diseases. Trypsin inhibitors reduce the incidence of certain cancers and potent anti-inflammatory nature (Gupta et al., 2016) ${ }^{[3]}$. Mothbean consumption of 4 times or more lweek compared with less than once a week have been associated with $22 \%$ lower risk of coronary heart diseases. (Bazzano et al., 2001) ${ }^{[4]}$.

The production of moth bean was 2.77 lakh tonnes in India during 2012-2015. Moth bean is commonly grown in arid areas of India and is consumed either as such after cooking or after germination and cooking. Moth bean is the unexploited legumes of the tropics and subtropics grown mostly under dry-land agriculture. The chemical composition is comparable with commonly cultivated legume. Like other legume this legume is deficient in methionine and tryptophan (Pawar and Ingle, 1988) ${ }^{[5]}$.

The nutritive value of grain legumes depends primarily on their nutrient and the presence or absence of antinutrient and toxic factors (Ramakrishna et al., 2006) ${ }^{[6]}$. Some simple and inexpensive processing technique, such as soaking, germination, and cooking are highly efficient for the reduction of anti-nutritional factors and for improving its organoleptic quality (Abusing et al., 2009) ${ }^{[7]}$. 
Germination of cereals has been used for centuries to soften the kernel structure, to increase nutrient content and availability; to decrease the content of antinutritive compounds, and to add new flavors without knowing the biochemistry behind these phenomena. Barley malting is the most widely known controlled germination process, used to produce malt for brewing purposes and food applications (Norja et al., 2004) ${ }^{[8]}$. Germination, a complex process causing physical, chemical and structural changes in grains, has been identified as an inexpensive and effective technology for improving cereal quality. The germination process is characterized by the growth of the embryo of the grain, manifested by the rootlets growth and increase modification of the contents of the endosperm (De Pinho Ferreira Guine \& dos Reis Correia, 2013) ${ }^{[9]}$.

Energy bars are supplemental bars containing cereals and other high energy foods targeted at people who require quick energy but do not have time for a meal. They are different from energy drinks, which contain caffeine whereas bars provide food energy. Energy in food comes from all three main sources: fat, protein, and carbohydrates. A typical energy bar weighs between 45 and $80 \mathrm{~g}$ and is likely to supply about 200-300 Cal (840-1,300 kJ), 3-9 g of fat, 7-15 g of protein, and $20-40 \mathrm{~g}$ of carbohydrates (Tiwari, 2017) ${ }^{[10]}$.

Fortification of plain and chocolate coated date bars resulted in an increase of protein, fat,fiber, ash, NA, K, CA, MG, P, $\mathrm{Zn}$ and all the essential amino acids. No difference was indicated in the control and fortified date bars which was stored up to 6 month (Sawaya et. al., 1983c) ${ }^{[11]}$.

Kamel and Kramer (1977) ${ }^{[12]}$ fortified dates prepared to form high protein date bars. The use of SCP in foods is, however limited to a certain level because of its high nucleic acid content.

\section{Materials and Methods \\ Materials}

The Raw material like Mothbeans, Dates, chocolate etc. will be procured from the local market of Parbhani. The proposed research was carried out in Department of Food process technology, College of Food Technology, VNMKV, Parbhani.

\section{Methods}

\section{Germination of moth beans}

Germination process is carried out by using method described by Mankotia and Modgil (2003). ${ }^{(13)}$ Moth bean grains were steeped in potable tap water for $12 \mathrm{~h}$. Grain to water ratio was $1: 3$. The soaked grains were tied in muslin cloth and allowed to germinate at ambient temperature $25 \pm 20 \mathrm{C}$. Grains were sprinkled with water. It took $24 \mathrm{hrs}$ for grains to germinate.

\section{Preparation of mothbean flour}

When the sprouts were $1-2 \mathrm{~cm}$ long germinated grains were dried in cabinet drier at $50 \pm 30 \mathrm{C}$ for $12 \mathrm{~h}$. The dried samples were milled to pass through a 40 mesh sieve. After grinding samples were kept in refrigerator in air tight plastic containers till further analysis was done.

\section{Preparation of date paste}

Seeds of the dates are removed. The seedless dates are blended with little amount of milk in mixer to form date paste.

\section{Preparation of Chocolate paste}

Dark chocolate compound from the market is melted to prepare chocolate paste.
Table 1: Preparation of chocolate coated Legume Bar with incorporation of different levels of germinated mothbean flour.

\begin{tabular}{|c|c|c|c|c|}
\hline Ingredient & $\mathbf{T}_{\mathbf{0}}$ (Control) & $\mathbf{T}_{\mathbf{1}}$ & $\mathbf{T}_{\mathbf{2}}$ & $\mathbf{T}_{\mathbf{3}}$ \\
\hline Germinated Mothbean flour $(\mathrm{g})$ & 0 & 10 & 20 & 30 \\
\hline Date paste $(\mathrm{g})$ & 100 & 90 & 80 & 70 \\
\hline Chocolate $(\mathrm{g})$ & 100 & 100 & 100 & 100 \\
\hline
\end{tabular}

\section{Preparation of chocolate coated legume bar}

Selected mothbeans were germinated for $24 \mathrm{~h}$. Legume bar was prepared by using mothbean flour and date paste with different proportions Viz., 30:70, 20:80 and 10:90. The mixture of date paste and mothbean flour is slightly heated to form a thik mass for 2-3 min with continuous stirring for uniform mixing and moulded into suitable size and shape. After cooling, the bar is coated with liquid chocolate compound and freezed at $0-4^{0} \mathrm{C}$. The prepared bar were subjected for sensory evaluation using 9 point hedonic scale.

\section{Flow sheet for preparation of chocolate coated legume bar}

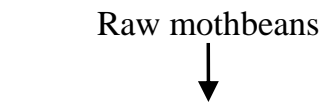

soaking of mothbeans for $12 \mathrm{~h}$

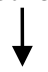

germination within $24 \mathrm{~h}$

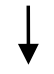

removal of germs

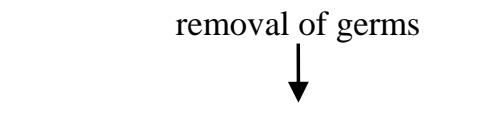

preparation of mothbean flour by drying

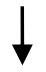

preparation of date paste with milk

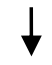

mixing of mothflour with date paste

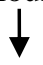

Slight heating with continuously stirring for uniform mixing

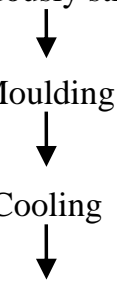

Chocolate coating

Freezing and packaging

\section{Results and Discussion}

\section{Organoleptic evaluation of energy bar}

The different proportios of products $\left(\mathrm{T}_{1}, \mathrm{~T}_{2}\right.$, and $\left.\mathrm{T}_{3}\right)$ and control were made differently with different germinated mothbean flour, dates and chocolate to achieve a highly acceptable product. The organoleptic evaluation of energy bar carried out by a 10 semi trained panel member based on 9 point hedonic scale and the score were given by evaluating the sensory attributes for energy bar such color, appreance, texture, taste and overall acceptability which was compared with control sample and expressed in table 4. 
Table 2: Sensory Evaluation of chocolate coated legume bar

\begin{tabular}{|c|c|c|c|c|c|}
\hline \multirow{2}{*}{ Treatments } & \multicolumn{5}{|c|}{ Sensory Characteristics } \\
\cline { 2 - 5 } & Colour \& Appearance & Flavour & Texture & Taste & Overall Acceptability \\
\hline $\mathrm{T}_{0}$ & 8.5 & 7.5 & 8.6 & 7.0 & 7.90 \\
\hline $\mathrm{T}_{1}$ & 8.5 & 8.0 & 8.2 & 7.7 & 8.10 \\
\hline $\mathrm{T}_{2}$ & 8.5 & 8.5 & 8.0 & 8.0 & 8.25 \\
\hline $\mathrm{T}_{3}$ & 8.5 & 8.0 & 7.5 & 7.2 & 7.80 \\
\hline
\end{tabular}

Sensory analysis was carried out using 9-point hedonic scale. Sensory quality of whole chocolate coated legume bar on the basis of colour and appearance, flavour, texture, taste and overall acceptability are as shown in Table 2. All the samples are having same colour thus got same score (8.5). T2 sample got highest score in flavor and taste and least score to control sample $(7.5,7.0)$ respectively. While control sample got highest score in texture (8.6) and least to T3 (7.80). The overall acceptability of the legume bar has highest sensory score (8.25) for $T_{2}$ followed by $T_{1}$ (8.10), control sample (7.90) and at last $\mathrm{T}_{3}$ with least overall acceptability sensory score (7.80).

\section{Conclusion}

It can be concluded from results that energy bar prepared with 20:80 proportions of germinated mothbean flour to date paste was found to highly acceptable and recorded maximum score in case of all the sensory attributes. It could be concluded that good quality of energetic legume bar can be prepared using germinated mothbean and dates with chocolate coating enhances the sensorial as well as nutritional characteristics. Thus, all such health benefiting ingredients can be well utilized as a functional ingredient for preparation of legume bar with good nutritional and medicinal value which act as functional food product.

\section{References}

1. Ghavidel RA, Prakash J. The impact of germination and dehulling on nutrients, antinutrients, in vitro iron and calcium bioavailability and in vitro starch and protein digestibility of some legume seeds. LWT Food Science Technology. 2007; 40(1):1292-1299.

2. Fatema MZ, Salve RV. Effect of different pretreatment on trypsin inhibitor activity and nutritional composition of mothbean and its utilization in fortified cake.world Journal of Dairy and Food Science. 2011; 6(2):212-218.

3. Gupta N, Shrivastava N, Singh P, Bhagyavant S. Phytochemicl evaluation of moth bean (vigna aconitifolia L.) seeds and their Divergence. Biochemistry Research International, 2016.

4. Bazzano LA, HE J, Ogden LG, Loriac Myers L, Whelton PK. Legume consumption and risk of coronary heart disease in US men \& women: HANES I epidemiologic followup study. Archives of International medicines. 2001; 161(21):2573-2578.

5. Pawar VD, Ingle UM. Effect of germination on the functional properties of moth bean (Phaseolus aconitifolius Jacq) flours. J Food Sci Technol. 1988; 25:7-10.

6. Ramakrishna V, Jhansi Rani P, Rao R. Anti-nutritional factors during germination in Indian Bean (Dolichos lablab L.) seeds. World J Dairy Food Sci. 2006; 1:06-11.

7. Abusing AE, Hassan S, Amro B, Baiker EE. Fadil. Nutritional evaluation of cooked faba bean (Vicia faba L.) and white bean (Phareolus vulgaris L.) cultivars. Aust J Basic Appl Sci. 2009; 3:2484-90.
8. Norja AK, Wilhelmson A, Poutanen K. Germination:a means to improve the functionality of oat Journal of Agricultural and Food Science. 2004; 13:100-112.

9. De Pinho Ferreira Guine R, dos Reis Correia PM. Engineering Aspects of Cereal and Cereal Based Products: CRC Press, 2013, 53-55.

10. Tiwari P, Agrahari K, Jaiswal M, Singh A. Standardization and development of different types of energy bars. International Journal of Home Science. 2017; 3(1):370-372.

11. Sawaya WN, Khalil JK, Safi WJ, Khatchadourian HA. Date bars fortified with soy protein isolate and dry skim milk. Journal of Food Science. 1983c; 48:1503-1506.

12. Kamel BS, Kramer A. Development of high protein date bars and their suitability at different storage temperatures. Journal of food Quality. 1977; 1:359-362.

13. Mankotia K, Modgil R. Effect of Soaking Sprouting and Cooking on Physico-Chemical Properties of Moth Beans (Vigna aconitifolia). Journal of Human Ecology. 2003; 14(4):297-299. 